\title{
Shades of irony in the anti-language of Amos
}

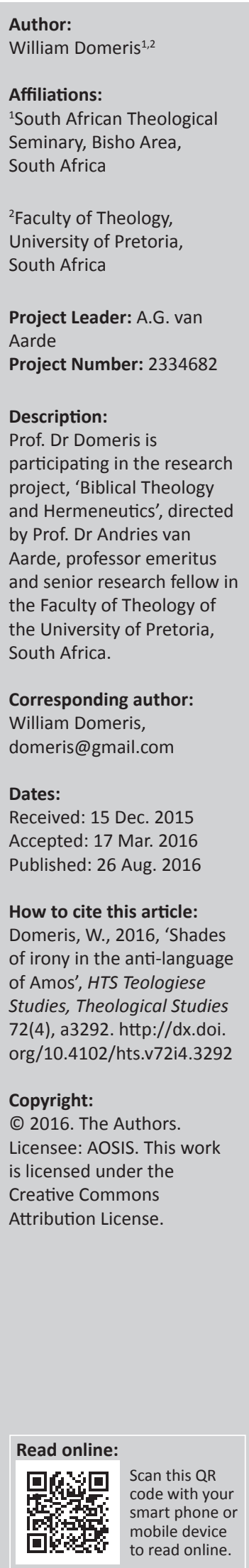

The rhetoric of Amos includes a wonderful mixture of humour and threat, sarcasm and irony, hyperbole and prediction. Holding the fabric of this conversation together is Amos's place within the prophetic minority - the Yahweh-only party (his anti-society). Making use of sociolinguistics, and particularly the idea of anti-language, I take a closer look at Amos, including his use of overlexicalisation, insider-humour and all the shades of irony one might expect. Typically of a member of an anti-society, Amos exaggerates the differences between insider and outsider, in this case, speaking of 'ivory houses', 'the cattle of Bashan' while appealing to his successful attempts to save the rich from the wrath of God. The offenses of the outsiders are sometimes crystal clear and at other times shrouded in metaphor, and so too is the fate of these people. In reading Amos, we are constantly in danger of falling victim to the persuasive power of his rhetoric. We are drawn into the world of Amos, quickly accepting his boundaries and the ideology of his anti-society, his depiction of reality and his stark caricature of the rich. The rhetoric is persuasive and the irony is divisive forcing a choice of black and white, believer and unbeliever, rich and poor, oppressors and oppressed. We struggle to swim against the current and instead long to respond to Amos's invitation to live (Am 5:5) - perhaps even to discover that elusive hope at which the book hints:

Most of history has been the forging of structures of security and appropriate loyalty symbols, to announce and defend one's personal identity, one's group, and one's gender issues and identity. (Rohr 2011:4)

\section{Introduction}

The rhetoric of Amos represents a wonderful combination of humour and threat, sarcasm and irony, hyperbole and prediction. Holding the fabric of this conversation together, I believe, is Amos's place within the prophetic minority - the Yahweh-only party, champions of ethical monotheism. Making use of sociolinguistics, and especially the notion of an anti-language, I argue that one can interpret the text of Amos in a way which makes good sense in the historical, social and religious context of the prophet's time.

Academic research on the book of Amos, in spite of the book's brevity, turns out to be voluminous (Carroll 2002). Although there is considerable consensus around the book's emphasis on justice and its social context (Matthews 2012:79-88), scholars are divided between two approaches, namely the synchronic approach which treats the text more or less as a unity (Andersen \& Freedman 1989; Möller 2000; Paul 1990; Smith 1989) and the diachronic approach which does not (Coote 1981; Jeremias 1988; Rottzoll 1996; Wolff 1977:106-118), by envisioning instead a series of redactionary strata. In this article, I propose to treat the text of Amos as 'closely crafted, artfully stylized composition' (Hubbard 1989:101) and following the lead of Möller (2003), I will use sociolinguistic and rhetorical models in defining the text's essential structure.

\section{Sociolinguistics}

Sociolinguistics has been recognised as a helpful key for the study of the Hebrew Bible (Polak 2006), providing important insights into some of the ways in which biblical writers sought to move their audiences (Cotterell 1997). In particular, this article will make use of the notion of anti-language which derives ultimately from the writings of the sociolinguist, Michael Halliday. Halliday is best known for his understanding of language as a social semiotic (Halliday \& Mathiessen 2004). He (1976:573) defined anti-language as the language of an anti-society, 'a society that is set up within another society as a conscious alternative to it'. This society (Halliday 1976:573), 'provides an alternative social structure, with its system of values, of sanctions, of rewards and punishments; and then becomes the source of an alternative identity for its members, through the patterns of acceptance and gratification'; in effect, it is 'an alternative reality' (Halliday 1976:575-576). Halliday (1976:570) concludes, 'This gives to anti-language 
a special character in which metaphorical modes of expression are the norm'. For example, anti-language creates its own form of insider-speak contrasting with the perceived threats of the outsiders.

Among scholars of the Bible, Malina (1985) was the first to make use of Halliday's work, in his study of the Fourth Gospel. Subsequently, the twin notions of anti-society and anti-language have been used in the social science commentary on the Gospel of John (Malina \& Rohrbaugh 1998:7-14, 32-33, 46-48, 59-61). Among the studies of the Hebrew Bible, Stulman (1995) developed the notion of insider-outsider discourse and applied this to Jeremiah. In my articles on Jeremiah (Domeris 1994, 1999), I have illustrated the manner in which the prophet Jeremiah used a form of anti-language to create caricatures of the popular religion of the state and its followers. In defence of his position as a member of the Yahweh-only party, Jeremiah used irony, satire, sarcasm, humour and deliberate distortion to achieve his purpose (Domeris 1994:9-14). His vivid metaphors poked fun at his opponents and their veneration of other deities - they are the lusty donkeys chasing after their desired lover-deities (Domeris 1999:254-256). Not until we pause and step back for a moment can we see Jeremiah's genius at work. We are, then, able to appreciate his use of irony, his unforgettable metaphors, and the other indications of his use of 'anti-language', whether deliberate or not (Domeris 1999:253-256). Subsequently, Robert Carroll saw merit in the idea of anti-language for the study of Jeremiah (1996:81), as did Brueggemann (2006:64), Raphael (2011:115), Epp-Tiessen (2012) and, with application to the book of Revelation, Schüssler Fiorenza (2007:5).

Albertz (1994) has described the prophets, like Amos, as gathering 'a small group of disciples around them, among whom their provocative words found a hearing and were handed down' (1994:164), concluding that 'In this way, the total prophetic opposition for the first time in the history of Israelite religion called forth a religious opposition literature' (1994:164). I suggest that Albertz's notion of a prophetic 'opposition group' corresponds to the notion of an antisociety, whereas his idea of prophecy as 'religious opposition literature' is akin to anti-language. Halliday (1978:178-179) writes that anti-language is 'consciously used for strategic purposes, defensively to maintain a particular social reality or offensively for resistance and protest'. So a prophet, like Amos or Jeremiah, would use anti-language to maintain the social reality of his followers and to distance that reality from the hegemony of the broader society.

In the book of Amos, there is much that is novel. Dell (1995:59) finds distinction in both form and content of the book of Amos - 'On the level of the content of the message he put across, and on the level of the forms he employed in a radically new way, in a radically new context'. In seeking to do justice to the words of Amos, what better place to start than with his intrinsic ideology?

\section{The Yahweh-only party}

Iron Age Israelite religion has been described, in all its complexity, by scholars like Albertz (1994:(1)156-195), Hess (2007) and Noll (2013). In the time of the monarchy (Iron II), the dominant state religions consisted primarily of the worship of Yahweh, but it was in concert with the veneration of Asherah, Baal and other deities (2 Kings 23). Noll (2013:323) writes, 'This diversity is not surprising. There were no organized religious institutions beyond the state-sponsored patron-god religions, and even the religion of the state did not require an orthodoxy (a set of defined "correct beliefs") except with respect to maintaining the population's loyalty and payment of taxes'. Such indeed is also the evidence of the archaeological discoveries, including the enigmatic pillar figurines, which characterise the excavations of Iron Age sites across both Israel and Judah during the time of the United and Divided Monarchy (Keel \& Uehlinger 1998:228-232; King 1988:88-107; Mastin 2004; Paul 1990:194-198, 210-212, 268-272; Shiloh 1984:17).

Amos, like Jeremiah (Domeris 1999:259-262), represented the minority 'Yahweh-only' Party, a form of anti-society. According to Lang (1983), the prophets of the period of the monarchy represented a minority position, within the kingdoms of Israel and Judah, anticipating the prevailing perspective of post-exilic Judaism. Hess (2007:330) describes the minority view as 'the prophetic religion of God (Yahweh) alone, superior to all Baals, covenantal, and requiring a personal and ethical as well as religious response from the people'. Speaking of the God of Amos, Andersen and Freedman (1989:43) write, 'In a world filled with deities and surrounded by nations with their own patron gods, Yahweh was not one among many or even primus inter pares. He was unique, a nonpareil'. At the other end of the spectrum was the imported cult of Baal from Tyre and between the two extremes, and 'coincident with the national cult ... was the popular religion' (Hess 2007:331), which the Yahweh-only party rejected.

\section{The hymns of Amos}

The oracles of Amos represent a unique opportunity to reflect on the beliefs of the Yahweh-only group. Among these oracles of Amos, we find three 'hymns' which celebrate Yahweh (Am 4:13; 5:8-9 and 9:5-6). Wolff (1977:215-217) reasons that the hymnic sections belong together and should be assessed together. Crenshaw (1975:152-153) describes the three hymns as 'hymnic affirmations of divine justice', whereas Möller (2003:115) argues that they are best understood as 'lending special force to Amos's message of judgement by stressing as they do, Yahweh's destructive power'. Scholarly attention (Möller 2000:114-116) has focused on the possible original cultic context for these hymns, and whether or not the hymns were inherited by Amos, compiled by Amos, or are the additions of a later scribe. If indeed, Amos stands as an early representative of the Yahweh-only movement, as I believe he does, then these hymns might be the expression of that movement. To use a metaphor drawn from archaeology, 
these literary creations, I suggest, may represent a very early stratum in the history of the worship of Yahweh-alone and so deserving of a more careful scholarly study.

These three powerful stanzas are resonant with ancient metaphor, and attest to the wonder of Yahweh. The first hymn (Am 4:13) focuses on Yahweh as the creator of the mountains and the wind, who reveals himself to humankind, and marches as a warrior deity, ending with the identification his name is Yahweh, the Lord of Armies. The second hymn (Am 5:8-9) speaks of the creation of the Pleiades and Orion, describing Yahweh as the one who turns darkness into light, or light into darkness, who controls the waters of the sea and who brings destruction on the mighty, and their fortresses. Again the identification with Yahweh is made. The third hymn (9:5-6) uses imagery reminiscent of an earthquake (cf. Am 1:1) and describes the creation of the vault of the heavens and again refers to God's power over the sea, ending with 'his name is Yahweh'. Three striking testimonies are present here, each one testifying to the uniqueness of Yahweh, as creator and controller of the natural world. In addition, there are two solemn aspects - Yahweh reveals himself (4:13) and he causes people to mourn (9:5). Paul (1990:39) writes 'the shattering sound of the voice of the warrior Deity produces a cataclysmic reverberation and destructive upheaval in the world'.

Dempster (1991) speaks of a deliberate rhetorical strategy in the content and arrangement of the hymns, which draws attention to God's role as the universal judge - the one Israel will ultimately have to face (Hubbard 1989:97). From the outset, Amos identifies his ideological commitment to Yahweh of Jerusalem as the source of his message: 'The Lord shall roar from Zion, and utter his voice from Jerusalem' (Am 1:2; Möller 2000:119). Wolff (1977:101) writes, 'That Yahweh is the only God of Israel and of the world of nations is not the theme of his message but its self-evident presupposition'. This is Yahweh, Lord of Armies, whom Amos proclaims as the source of the judgement on the peoples of Israel and Judah. Poetically, Andersen and Freedman (1989:43) write: 'He was the maker and ruler of the universe who alone was worthy of the title, who brooked no rivals, had no consort or progeny, was dependent on no one and nothing, but exercised a full monopoly of power and authority'. This focused belief is the theological and ideological platform for Amos' anti-society and the springboard of his polemic against the public worship of the time.

\section{Amos's use of anti-language}

Anti-language involves 'all kinds of verbal play, from puns to intertextuality, employed to generate an alternative conceptual reality over against a dominant culture' (Hurtgen 2012). The book of Amos is an intricate tapestry of word plays (Wolff 1977:96), heptads and seven-plus-one series (Limburg 1987), chiasm (Carroll 2002:45), interspersed with polysemy (Carroll 2002:46), the rhetoric of entrapment (Möller 2000:214-216) and various other tragic and comic forms (Wood 1998).

\section{Irony and a fouble audience}

Paramount within the ambit of verbal play is Amos's use of irony, so ably illustrated by Sharp (2009). Booth (1974:31) writes, 'To understand irony is to perform an intricate intellectual dance together'. Caird (1980:104-105) explains that irony constructs 'a double audience, the first understanding nothing beyond the face value of the words, the second seeing both the deeper meaning and the incomprehension of the first'. Irony separates those who understand 'nothing beyond the face value of the words', from those who see 'both the deeper meaning and the incomprehension of the first' (Caird 1980:104). In a similar vein, Timmer (2014) speaks of the way in which the text of Amos addresses two groups, one to be rewarded and the other to be punished by Yahweh, the ultimate authority. In his deft use of irony, Amos lays the grounds for affirming the faith of the insider group and exposing the flawed thinking of the outsider group.

What does Amos see as the besetting sins of the outsider? Hubbard (1989:87) specifies two issues, namely 'the abuse of power in the social realm' and 'compromise with paganism in the religious'. The latter claim is open to debate, with some scholars (Carroll 2002:268; Möller 2003:143) preferring to think of Amos as critiquing the general worship of the people, rather than their idolatry. For example, Daniel Carroll (2002:268) speaks of the population at large coming under scrutiny for their 'complicity in the national cult and social sin' (Am 3:1). He concludes (2002:268) that the rulers and the governed share the Yahwistic faith at different levels and in various ways as all move about in a world that claims YHWH but does not truly meet him at the sanctuary'. In sum, Israel's worship, although enthusiastic, lacked, in the opinion of the Yahweh-only party, any depth and meaning. Poor and rich, although otherwise treated separately, are jointly complicit in this respect (Möller 2003:268).

\section{Irony and the religion of the people}

Irony abounds. From his anti-society perspective, Amos, the prophet, offers a withering critique of the cult and beliefs he observed in Bethel. Israel is told to prepare to meet their God (Am 4:12) - the creator God, and, in case they have forgotten, 'Yahweh, the God of Hosts, is his name' (Am 4:13; 9:6). This is the uncomfortable God who announces 'I hate, I despise your feasts, and I will take no delight in your solemn assemblies' (Am 5:21), their offerings will be rejected (Am 5:22) and their songs remain unheeded (Am 5:23). Such a fearful God, a Warrior God, will not hesitate to destroy the temple at Bethel (Am 9:1 cf. 2 Ki 23:15-18).

Sharp (2009:129) sums up the message of Amos when she writes, 'The audience of Amos gradually loses its grasp on its identity as the prophet destroys piece after piece of Israel's tradition history. But Amos also supplies them with the one thing that is needful: 'Seek me', thunders the God of Amos, 'and live!'(Am 5:5)'. Viberg (1996) writes:

The use of irony ... provides a means for the prophet to bridge the gap between himself and his audience, briefly taking their 
side with the help of their ideology, only to puncture their complacency with the realistic if unpalatable word of YHWH. (p. 114)

For Amos (Am 5:26), the experience of the wilderness wanderings mirrored the present popular religion, with the people carrying symbols of 'their king', their 'images', 'the star of their god' - 'which they had made'. Through the ironical use of the possessive form, the worship of the outsiders is distanced from what Amos perceives to be the true worship of Yahweh. So when Amos asks, 'Did you bring me sacrifices and offerings in the 40-year sojourn in the wilderness, $O$ house of Israel?' (Am 5:25), the implied answer is a resounding 'No!' (Eaton 1997:39). Were they offering for me? (Am 5:25) No they were for the images of the star deities. Paul (1990:194-197) presents a convincing case for the antiquity of the wor ship of the two deities mentioned (in Am 5:26), making them relevant to the time of Amos and not just to the later Post-Exilic period. 'Amos in his parody of these gods, whose names are cacophonously vocalised on the pattern of Hebrew שישקוּץ ("detestable things"), further denigrates them satirically' (Paul 1990:196). Note the irony here - 'The Lord of all the astral hosts will deport them along with their astral deities' (Paul 1990:198).

Amos continues his satirical monologue. The images are of their own making (Am 5:26), pieces of nothingness (Am 6:13) and nonsense like horses galloping across soaring rocks or ploughing the sea with oxen (Am 6:12) - a riddle for the insider reader (Cooper 1988). The contagion has spread and so 'the high places of Isaac shall be desolate, and the sanctuaries of Israel shall be laid waste' (Am 7:9). A spate of mocking titles flows from the lips of Amos - 'the sin of Samaria', 'your god, O Dan', 'the way of Beer-Sheba' all doomed to fall and never rise again (Am 8:14). The multiple titles used by Amos carry overtones of ironic humour for the insider reader adding to their sense of superiority over the implied outsiders.

In dramatic detail, Sharp (2009:151-169) demonstrates Amos's rhetorical skill, as he simultaneously undermines Israel's confidence in her historical traditions and her belief in her unique position vis-à-vis Yahweh. In terms of anti-language, Amos is redefining the true people of God to include only the insiders and exclude the outsiders. The great claims of the Israelites to a unique position as the covenant people (Sharp 2009:156) collapse as Amos pulls the rug out from under them: 'All the basic props and supports of the nation will utterly fail them: Neither their lavish cult (Am 5:21-24), nor their extensive wealth (Am 6:1-6), nor even their military successes (Am 6:13) will offset their destined fate of deportation' (Paul 1990:198).

Effectively, as representative of his anti-society, Amos is redrafting the rules to suit the prophetic minority in their perceived struggle against a lapsed Israel. He resorts to insider-humour to the detriment of his perceived opponents the ruling elite of Israel and those, willing or not, who support them. Amos concludes that they are no better than the Ethiopians, the Philistines or the Syrians (Am 9:7).
For Sharp (2009:155) this is Amos's coup de grâce: [T]hat glorious Exodus, the essential hallmark of identity for ancient Israel and the foundation of her story of redemption, is just another event in the history of the nations of the earth. The Lord delivers all and judges all.

Amos, according to Möller (2003:116), and Wolff (1977:97), uses the technique of using the voice of the people against them (e.g. 7:10-17; 4:1; 6:13)'. Carroll (1992:202) adds that 'whenever others beside the prophet speak in this textual world they condemn themselves with their own words'. In addition, according to Smith (1989:14), such quotations serve also to capture elements of the popular theology $(2: 12$; $4: 1 ; 5: 14 ; 6: 13 ; 7: 16 ; 8: 4-6 ; 14: 9-10)$. In the light of Amos' use of anti-language the verb 'caricature' might be more accurate.

\section{Overlexicalisation}

Apart from irony, another indication of anti-language is overlexicalisation or 'multiple words used for concerns of the sub-group' (Hurtgen 2012:74). Amos uses various names used for the outsiders, including: Israel (2:6), Children of Israel (2:11), Daughter of Israel (3:1), Virgin Israel (5:2), People of Israel (7:8), Jacob (3:13), Joseph (5:6) and Isaac (7:9). This diversity of titles was examined in detail by Andersen and Freedman (1989:98-139), who explored the possibility that some titles referred to the Northern Kingdom of Israel only and other titles included both Israel and Judah. An alternative solution is to find in this rich diversity one more indicator of Amos's use of anti-language; an integral part of his extended caricature of the outsiders. In sharp contrast, the Insiders are described as 'my people' (Am 9:14), 'the remnant' (Am 5:15) and the 'kingdom of David' (Am 9:11).

Overlexicalisation also appears in the variety of terms used for the object of outsider worship. Although Amos and his followers worship only Yahweh, Lord of Hosts, the outsiders are the misguided worshippers of 'deities' like - 'the sin of Samaria', 'your god, O Dan' and 'the way of Beer-Sheba'; such 'deities' as are doomed to fall and never rise again (Am 8:14). The irony is that the people may wish to claim that they are, in fact, worshipping Yahweh, and not some strange deity. However, in the eyes of Amos, the people are as guilty as if they were worshipping strange gods. The deities are 'pieces of nothingness' (Am 6:13), and symbols of 'their king', which 'they had made' (Am 5:26). This is the voice of the prophetic minority speaking against lapsed Israel. Therefore, they are no better than the Ethiopians, the Philistines or the Syrians (Am 9:7).

\section{Humour at the expense of the outsider}

For the insiders, aware of what Amos is doing, it is easy to trace the threads of his logic and argument. They are alive to the nuances of his humour, can decode his irony, recognise his caricatures and applaud his outspokenness. Consider Amos (Am 7:1-6), where the prophet, from the lofty-heights of his insider speech, represents himself as a divinely appointed mediator, who causes even the Almighty pause for thought and due repentance. 
Personifying the constructed voice of the outsider is the High Priest Amaziah, who in the creative framing of the discourse perceives Amos as an intruder - a foreigner to be disregarded and an unwanted guest at the King's chapel. His oracles are opaque and he deserves to be sent packing. The single narrative passage (Am 7:10-17) is full of irony as several scholars have noticed (Sharp 2009:151 fn. 71). Even in Amos' denial of prophetic status, there is an ironical twist. Soggin (1987:7-8) reasons that 'I am not a prophet' (Am 7:14) is past tense referring to the time before Amos was called by God, thus introducing again an element of irony into the equation. Viberg (1996:111) offers an even more ironical reading:

The three nominal clauses in v. 14 form an example of pretended self-abasement by Amos, in which he claims to the mighty priest at Bethel to be totally insignificant. I am certainly not a näbî'. No, I am just a simple worker! You, the priest at Bethel, have totally overestimated my humble status! (p. 111)

Stripping the pericope of its mystique, Noll (2013:350) gives the text another slant:

Amos spoke in the name of Yahweh of Jerusalem (Am 1,2). This would have been a satellite god in the eyes of the king of Samaria, whose god was ... Yahweh of Samaria. The bureaucrat who responded to Amos did so with kindness, but Amos is depicted lashing out at this priest with a gratuitous judgment against him. (Am 7:10-17)

Amaziah apparently wished to protect the prophet 'from potential royal reprisals' (Noll 2013:350). The insider readers of Amos see a different story to that expressed by Noll (2013:350-351), namely a corrupt high priest being challenged by a righteous prophet. These readers know that in their reading and rereading of the oracles, the victorious Amos will keep returning. They smile scornfully at the bombast of Amaziah and relish the cutting prophetic invective of Amos and his words of doom. Indeed, for the generations of insider readers, Amaziah is forever the loser in the honour versus shame riposte.

\section{Sarcasm and Israel's identity}

The public audience of Amos, the attendees of the shrine of Bethel, form the foil for his irony, and the target of his threat. 'What surfaces in these readings is a deeply religious construction of reality, with multiple intersecting interests and complicity in self-deluding, and finally fatal, misconceptions about life and the Deity by every sector of the population' (Carroll 2002:47). The audience believe that they are protected by their elevated status as the chosen people of God, the people of the Exodus and the recipients of the Covenant but in the eyes of Amos, and his anti-society, all that is forfeit.

In reference to Amos 4:4, Sharp speaks of 'biting sarcasm' and of 'skewering his audience with a proleptic ironic lament' (2009:151). The same comment might be made of chapter seven, where addressing the outsider, Amos twice asks 'How shall Jacob stand for he is so small?' (Am 7:2,5). The smallness of Jacob is thrown into relief by the size of locusts $(7: 1-3)$ on one side and by the size of the fire (7:4-6 being able to devour the deep) on the other. Amos mocks the greatness of Israel; of their city walls and fortresses; of their wealth and prosperity they are actually rather small - at least in the sight of God, and of the Yahweh-only party of Amos. It is their failure to truly worship Yahweh, which makes them small even though they live in pseudo-palaces (Am 3:10-11).

\section{Hyperbole and the wealthy class}

The singular critique of the wealthy class and their oppression of the poor and weak is without a doubt the most memorable aspect of Amos (Domeris 2007:104, 112-114; Hoppe 2004:71-72). Although scholars might debate the precise nature of the oppression (Houston 2004), there can be no doubt that the poor suffered at the hands of the powerful. However, even here, one needs to read the oracles of Amos with care, because ultimately as Möller (2003:31) has shown, their purpose is persuasive - and they serve the vested interest of the insider reader.

Masterfully, Amos creates the impression of a unified wealthy class, who take every opportunity to abuse the poor and trample their heads into the dust (Am 2:6-8) (Hoppe 2004:72). To be sure, Amos can be quite precise about his opponents 'the notable men of the chief of the nations, to whom the house of Israel come!' (Am 5:12), which leads Hoppe (2004:71) to write 'He painted a picture of the wealthy that made them look heartless and dishonest'. We suggest that the portrait, although in many ways a true likeness, also had elements of caricature present - the 'lying on ivory beds; stretching out on couches', 'singing idle songs' and 'inventing instruments like David' (Am 6:4-5), anointing themselves and drinking 'wine by the bowlful'. Paul (1990:207-208) captures the essence of this indictment as he writes, 'After censuring their culinary and musical pamperings, Amos now proceeds to satirize their excessiveness in drinking'.

The diatribe continues - they 'trample on the needy' and 'annihilate the poor of the land' (Am 8:4b; Paul 1990:256-257). Crushingly, Amos tells them that God hates 'their fortresses' (Am 6:8b), perhaps an ironical reference to their attempt to build fortress-like homes, hence the sarcastic phrase 'Pride of $\mathrm{Jacob}^{\prime}$ (v 8a).

The oracles speak sarcastically of 'the temple of their God' (Am 2:8) (Paul 1990:86), 'composing songs as if they were David' (Am 6:5) (Paul 1990:207), and behaving like 'the cattle of Bashan' (Am 4:1), while appealing to Amos's own insider relationship with Yahweh (Am 3:7-8). Even when they worship at Bethel or Gilgal, they are simply 'the children' of Israel (Am 4:5) whose attempt at worship goes badly wrong (vv 4-5). It pleases them, but not the true God, Yahweh. Consequently, Israel is told to prepare to meet their God (Am 4:12) - the creator God, and 'Yahweh, the God of Hosts, is his name' (Am 4:13; 9:6). God sings a dirge over them (Am 5:1-3). ' $[\mathrm{H}]$ is funerary lament is the more shocking when it is realised that he is actually mourning the death of his listeners themselves!' (Paul 1990:159). 'The virgin (deep sarcasm) is fallen' never to rise again (Am 5:2). Israel is the deflowered virgin, by virtue of her failure to remain true to Yahweh, 
so the term becomes a reproach, confusing for the outsider, but obvious to the insider.

Apart from a few concrete examples (Am 2:6-8; Am 8:4-6), when Amos comes to list the sins of the outsiders, he is short on details (Möller 2003:256). His language is cloaked in metaphor: 'selling the righteous for silver and the needy for a pair of shoes' (Am 2:6b) or 'trampling dust onto the heads of the poor' and 'turning aside the way of the oppressed' (Am 2:7a). By attempting to define the precise nature of the act, modern interpreters may simply be further muddying the waters, which the prophet intended to be dark. We can be sure that not all the wine drunk was taken in fines (Am 2:8), nor did all the oppressors necessarily hate and abhor truth in court (Am 5:10-12); but to focus there is to miss the point of Amos's anti-language - namely his effective caricature of the ruling class. They are simply the collective 'other' in the antilanguage of Amos. Here we see hyperbole at work (Gowan 1996:421), which serves to create the image of a debauched and decadent ruling class, who are so clearly deserving of judgement (Am 9:2-4).

\section{Prediction and the fate of the outsiders}

Amos builds up his picture of the oppressors so that he can give free reign to oracle after oracle describing their fate at the hand of Yahweh, the universal judge. The city of Samaria, according to chapter six, will be delivered up (Am 6:8), and the outsiders are warned 'they will be the first to become captive' (Am 6:7). An anonymous nation (Paul 1990:220) will be raised up against Israel (Am 6:14), to oppress her from north (Lebo-Hammath) to south (Arabah). Interestingly, the fate of Israel, as the ones oppressed, will be a mirror of the experience of the present oppressed poor - yet another ironical twist.

Some of the oracles speak of deportation and alienation (e.g. Am 5:5 - Gilgal), but even 'beyond Damascus' (Am 5:27), is 'anonymously vague to exacerbate the psychological tension' (Paul 1990:198). Amos prophesies that Amaziah will die in a foreign land (Am 7:17), and that Jeroboam will die by the sword (Am 7:11). Noll (2013:350), however, notes that Jeroboam II, rather dying by a sword, instead went on to extend Israel's borders from Lebo-Hammath to the sea of Arabah (2 Ki 14:25a), in fulfilment of a prophetic oracle, delivered by a man called Jonah (2 Ki 14:25c). Amos does indeed speak of Israel being led away captive (Am 7:11) but the timing is vague as is, the real threat, that the religious sites of Isaac and Israel (derogatory names for the outsider) will be destroyed (Am 7:9). In the final chapter, Amos returns to the notion of captivity, but again it is simply in passing (Am 9:4), as God commands an impersonal sword to slay them. We note, throughout, the emphasis, in line with his connection to the Yahweh-only ideology, that this is Yahweh, Lord of Armies speaking (Am 5:27; Cf. also Am 6:8 and Am 9:5).

By far the majority of the oracles deal with a fate more graphic than actual 'whether by fire, earthquake or foreign army'
(Hubbard 1989:88). The emphasis as is typical of anti-language relies heavily on metaphor. In this case, the metaphors are extremely vivid. So, the outsiders are warned that Yahweh will crush them like a heavy cart (Am 2:13) (Smith 2001:261); they will lose both swiftness and strength (Am 2:14); they will be unable to fight (Am 2:15) and will flee away naked (Am 2:16). An unnamed enemy (Paul 1990:118) will descend upon the land, sapping strength and plundering fortresses (Am 3:11); the horns of the altar - symbol of sanctuary - will be broken off (Am 3:14). Yahweh will destroy winter and summer houses alike, including the ivory mansions (Am 3:15). The irony here is that the ivory was probably inlays of ivory in wooden façades (King 1988:139) rather than an actual house made of ivory.

In contrast to Gilgal's exile, Bethel, is simply told that she will come to nothing (Am 5:5) as Amos continues vaguely to speak of 'sudden destruction of the strong' (Am 5:9), of wailing in the streets (Am 5:16) where farmers are summoned as skilful professional wailers (Am 5:16). In place of drunken songs, wailing will fill the vineyards (Am 5:17). Even the hope of the day of Yahweh, apparently believed to be a day of victory for Israel, turns out to be, ironically, dark and deadly (Am 5:18-19).

Probably, the big threat is that of spiritual poverty of word of God (Am 8:11-12; Soggin 1987:139) or the destruction of the temples (Am 3:14; 5:5-6; 6:11; 9:1; Möller 2003:138). For Amos, hegemonic symbols, including sacred shrines like Bethel, have lost their claim to legitimacy - 'And the high places of Isaac shall be desolate, and the sanctuaries of Israel shall be laid waste; and I will rise against the house of Jeroboam with the sword' (Am 7:9). In Chapters eight and nine, the climax of the book, Amos takes his metaphors to a new level. The very land will rise and fall like the Nile (Am 8:8) and the sun will lose its rhythm (8:9). Desperate to escape from God, people will dig down into Sheol (9:2a) or climb up into the heavens (Am 9:2b), even (ironically) climbing to the top of Carmel (Am 9:3a) or slinking around at the bottom of the sea only to be devoured by Leviathan (Am 9:3b). Israel will be shaken in the sieve among the nations, and no kernel will land on the ground (Am 9:9). Israel will be either trapped like the chaff in the sieve, or like the finer wheat scattered among the nations (Paul 1990:286-287). All the guilty ones will die (Am 9:10a), even as they claim that God would protect them from evil (Am 9:10b). What a picture of sheer hopelessness!

\section{Elements of hope}

If Amos intends to persuade, as his rhetoric suggests, then logically the message needs to include a ray of hope (Eaton 1997:38; Hammershaimb 1970:170), if only for the insiders and that burden is carried by the concluding verses of the book (9:11-15; Hubbard 1989:98). Precisely the sense of paradox present here has led some scholars (e.g. Wolff 1977:351-352) to view these verses with great suspicion. Once again, antilanguage comes to our aid, suggesting that at the climax of the book, like an evangelical preacher, Amos assures the 
faithful and appeals to the repentant. Sharp (2009), on the basis of her study of irony, explains:

Israel is accorded a measure of grace in the last verses of the Book of Amos. The final interpretative task for the rereader alert to irony is to determine two things: first, where the bitterly sarcastic judgement material stops and the lyrical restoration material begins: and second, how to read these two possibilities, judgement and promise together. (p. 164)

Looking back over the book, the insider reader might indeed have seen the earlier notes of this climatic overture (cf. 3:2, 12; 5:3-6, 14-15), to use a metaphor drawn from Smith and Page (1995:164). Carroll (2002:46) agrees: 'The eschatological message of hope at the end of the book is well integrated into the rest of the prophetic text, even as it makes the whole more complex and paradoxical'.

In these concluding verses, Amos gives free reign to the metaphorical nature of his anti-language, as he speaks of the ploughmen chasing the reaper, the one who treads grapes pursuing the sower; mountains dripping with sweet wine and melting hills (Am 9:13). In contrast to the outsider warning that 'every guilty one will be punished' (Am 9:10), Amos (Am 9:11-12), raises a glorious beacon of hope; 'On that day' - a day when God will recognise the fidelity of the insiders - God 'will raise up the fallen tabernacle of David' (Am 9:11). The image of the tabernacle stands in contrast to the solid buildings of the surrounding nations, as a further ironic note (Coniglio 2013). In the light of the anti-language of Amos, I suggest that this is not a reference to the political resurgence of the Davidic dynasty or even a rebuilding of the Jerusalem temple. But in the insider-speak of Amos, the whole oracle speaks of Yahweh's recognition of the true worshippers - the prophet and his circle of disciples.

What is now 'in ruins' will be rebuilt - not some physical rebuilding of a city, but the renewal of the fabric of the sullied worship of Yahweh, with its attendant harking back to 'the days of old' - a delightful whimsical touch (9:11). God will purify the worship, closing the breaches and raising up the ruins. Unity with Edom and other nations (9:12) who also seek the true God (Yahweh) will follow. Only this occasion is 'Yahweh' and 'Your God' (Am 9:15) linked (Hammershaimb 1970:143) as Amos focuses his full attention on the insider faction.

The true people of Yahweh, including a remnant of the nations called by my name (Am 9:12) will return to reclaim the land from those outsiders and they will know his abundance (9:13). The collective insiders are promised a return from 'captivity' and a time of rebuilding, planting vineyards and gardens, as Yahweh redistributes the land to the 'faithful remnant' (9:14), which may well include the faithful of other nations (Andersen \& Freedman 1989:898-905). This group, who are the redefined 'My People', will be the ones whom God will plant on the land, no more to be disturbed (Am 9:15).
So much for the insiders, but this begs the question of whether hope is also offered to the outsider. Carroll (2002:) poses a question:

Was the prophet's declaration of judgement final and without possibility of escape, or was it the case that the prophet warned his people of destruction in hyperbolic fashion while at the same time giving them glimpses of hope if they turned in repentance to Yahweh? (p. 46)

Sharp (2009) responds:

For to recognize the irony in prophetic indictment is possibly but just possibly - to escape its fatal grasp ... The chance to repent and thereby avert disaster always lingers in the shadowy unspoken that envelops prophetic irony ... If the prophetic word is heeded, it renders itself redundant'. (pp. 127-128)

In this too, there is irony; both for those who reject the prophetic word and are destroyed and those who accept it and are saved (Möller 2003:143; Sharp 2009:129-130). Ultimately, the dividing line is that drawn by Amos - the boundary separating insider and outsider, the members of the Yahwehonly party, like the members of the Qumran sect, against the rest of the world.

\section{Conclusion}

In conclusion, I have indicated some reasons for believing that anti-language allows us to appreciate Amos as a unified text; to see its irony as a means to an end; to highlight the implicit connection between the insiders and their worship of Yahweh alone; to offer an explanation for the multiplicity of terms for Israel and her gods; to recognise the portrait of the rich oppressors as caricature; and finally to reveal the double edged sword whereby Amos on the one hand affirms the insider and cautions them; and on the other pronounces doom for the outsider, with just a tantalising ray of hope - for those who can find a way through the maze of his language.

In alliance with the insiders, we long for hope, the very hope denied to the outsiders, yet offered to us. We want to share the promises, of their glorious future destiny. We want to know the safety of their boundaries and the security of their God as our protector. We want to be a part of Amos's safe yet slightly precarious (Sharp 2009:45) insider world.

\section{Acknowledgements Competing interests}

The author declares that he has no financial or personal relationships which may have inappropriately influenced him in writing this article.

\section{References}

Albertz, R., 1994, A history of the Israelite Religion in the Old Testament period (2 vols). SCM, London.

Andersen, F. \& Freedman, D.N., 1989, Amos: A new translation with introduction and commentary. Anchor Bible, Doubleday, New York.

Booth, W.C., 1974, A rhetoric of irony, University of Chicago, Chicago, IL.

Brueggemann, W., 2006, Like fire in the bones: Listening to the prophetic word in Jeremiah (Ed. by P D Miller), Fortress, Minneapolis, MN. 
Caird, G.B., 1980, The language and imagery of the Bible, Westminster, Philadelphia, PA.

Carroll, M.D., 1992, Contexts for Amos: Prophetic poetics in Latin American perspective Journal for the Study of the Old Testament Supplement 132, Sheffield Academic Press, Sheffield.

Carroll, M.D., 2002, Amos - the prophet and his oracles: Research on the book of Amos, Westminster, John Knox, Louisville, KY.

Carroll, R.P., 1996, 'Whorusalamin: A tale of three cities as three sisters', in B. Becking \& M. Dijkstra (eds.), On reading prophetic texts, pp.67-82, E J Brill, Leiden.

Coniglio, A., 2013, 'The tabernacle of David that is fallen' (Amos 9:11); an exegetical study of a moot expression', Liber Annuus Studii Biblici Franciscani 63, 137-156. http://dx.doi.org/10.1484/J.LA.5.105592

Cooper, A., 1988, 'The absurdity of Amos 6:12a', Journal of Biblical Literature 107 725-727. http://dx.doi.org/10.2307/3267633

Coote, R.B., 1981, Amos among the prophets: Composition and theology, Fortress, Philadelphia, PA.

Cotterell, P., 1997, 'Linguistics, meaning, semiotics and discourse analysis in NIDOTTE 1', in W.A. Van Gemeren, (ed.), New international dictionary of Old Testamen theology and e xegesis (5 Volumes), pp. 134-160, Paternoster, Carlisle, PA.

Crenshaw, J.L., 1975, Hymnic affirmations of divine justice. SBL dissertation series, Scholars Press, Missoula, MT.

Dell, K.J., 1995, 'The misuse of forms in Amos', Vetus Testamentum 45(I), 45-61. http://dx.doi.org/10.1163/1568533952581595

Dempster, S., 1991, 'The Lord is his name. A study of the distribution of the names and titles of God in the book of Amos', Revue de Biblique 98(2), 170-189.

Domeris, W.R., 1994, 'Jeremiah and the Religion of Canaan; a sociolinguistic approach', Old Testament Essays 7(1), 7-20.

Domeris, W.R., 1999, 'When metaphor becomes myth: A socio-linguistic reading of Jeremiah' in A.R.P. Diamond, K.M. O'Connor \& L. Stulman (eds.), Troubling Jeremiah (JSOT Supplementary Series 260), pp. 244-262, Sheffield Academic Press, Sheffield.

Domeris, W.R., 2007, Touching the heart of God: The social construction of poverty among Bible peasants (Library of Hebrew Bible/Old Testament Studies 466), Continuum, New York.

Eaton, J., 1997, Mysterious messengers: A course on Hebrew prophecy from Amos onwards, Zondervan, Grand Rapids, Ml.

Epp-Tiessen, D., 2012, Concerning the prophets: True and false prophecy in Jeremiah 23:9-29:32, Wipf and Stock, Eugene, OR.

Gowan, D.E., 1996, 'The book of Amos. Introduction, commentary and reflections', in L.E. Keck (ed.), The new interpreter's Bible. A commentary in twelve volumes. Vol 7. An Introduction to apocalyptic literature, Daniel. The twelve prophets, $\mathrm{pp}$. 337-431, Abingdon, Nashville, TN.

Halliday, M.A.K., 1976, 'Anti-Languages', American Anthropologist (New Series) 78(n3), 570-584. http://dx.doi.org/10.1525/aa.1976.78.3.02a00050

Halliday, M.A.K., 1978, Language as social semiotic: The social interpretation of language and meaning, Edward Arnold, London.

Halliday, M.A.K. \& Mathiessen, C.M.I.M., 2004, An introduction to functional grammar, 3rd edn., Arnold, London.

Hammershaimb, E., 1970, The book of Amos, Basil Blackwell, Oxford.

Hess, R.S., 2007, Israelite Religion: An archaeological and Biblical Survey, Baker Grand Rapids, MI.

Hoppe, L.J., 2004, There shall be no poor among you: Poverty in the Hebrew Bible, Abingdon, Nashville, TN.

Houston, W., 2004, 'Was there a social crisis in the eighth century?', in In Search of Pre-Exilic Israel (JSOT Supplement Series 406), pp. 130-149, T \& T Clark, London.

Hubbard, D.A., 1989, Joel and Amos: An introduction and commentary (Tyndale Old Testament Commentaries), Intervarsity Press, Leicester.

Hurtgen, J., 2012, 'Boy, (Achtung) baby, bomb: Anti-language in the songs of U2', in S.D. Calhoun (ed.), Exploring U2: Is this rock ' $N$ ' roll?: Essays on the music, work and influence of $U 2$, pp. 216-228, Scarecrow, Plymouth.

Jeremias, J., 1988, 'Amos 3-6: From oral word to the text', transl. S.A. Irvine, in G.M.P.D.L. Tucker \& R.R. Wilson (eds.), Canon, theology, and Old Testament interpretation (Festschrift B. S. Childs), pp. 217-229, Fortress, Philadelphia, PA.
Keel, O. \& Uehlinger, C., 1998, Gods, goddesses, and images of God, Fortress, Minneapolis, MN.

King, P.J., 1988, Amos, Hosea and Micah - an archaeological commentary, Westminster, Philadelphia, PA.

Lang, B., 1983, Monotheism and the prophetic minority: An essay in Biblical history and sociology (The Sacred World of Biblical Antiquity Series 1), Eisenbrauns, Winona Lake, IN

Limburg, J., 1987, 'Sevenfold structures in the book of Amos', Journal of Biblical Literature 106, 217-222. http://dx.doi.org/10.2307/3260633

Malina, B.J., 1985, The gospel of John in sociolinguistic perspective, The Center for Hermeneutical Studies, Berkeley, CA.

Malina, B.J. \& Rohrbaugh, R.L., 1998, Social-science commentary on the gospel of John, Fortress Press, Minneapolis, MN.

Mastin, B.A., 2004, 'Yahweh's Asherah. Inclusive monotheism and the question of dating', in J. Day (ed.), In search of pre-exilic Israel. Journal for the Study of the Old Testament Supplement Series 406, pp. 326-351, T \& T Clark, London.

Matthews, V.H., 2012, The Hebrew prophets and their social world. An introduction 2nd edn., Baker Academic, Grand Rapids, MI.

Möller, K., 2000, “Hear this word agains't you': A fresh look at the arrangement and the rhetorical strategy of the book of Amos', Vetus Testamentum 54(4), 499-518. http://dx.doi.org/10.1163/156853300506521

Möller, K., 2003, A prophet in debate: The rhetoric of persuasion in the book of Amos, Sheffield Academic Press, London.

Noll, K.L., 2013, Canaan and Israel in antiquity: A textbook on history and religion, 2nd edn., Bloomsbury, London.

Paul, S.M., 1990, Amos: Hermenia, Fortress, Minnepolis, MN.

Polak, F., 2006, 'Sociolinguistics: A key to the typology and the social background of Biblical Hebrew', Hebrew Studies 47, 115-162. http://dx.doi.org/10.1353/ hbr.2006.0025

Raphael, R., 2011, “'Whoring after cripples,” On the intersection of gender and disability imagery in Jeremiah', in C.R. Moss \& J. Schipper (eds.), Disability studies and Biblical literature, pp. 103-116, Palgrave-Macmillan, New York.

Rohr, R., 2011, Falling upward: A spirituality for the two halves of life, Jossey-Bass, San Francisco, CA.

Rottzoll, D.U., 1996, Studien zur Redaktion und Komposition des Amosbuches. Beihefte zur Zeiitschrift für die alttestamentliche Wissenschaft 243, De Gruyter, Berlin.

Schüssler Fiorenza, E., 2007, The power of the word: Scripture and the rhetoric of empire, Fortress, Minneapolis, MN

Sharp, C.J., 2009, Irony and meaning in the Hebrew bible, Indiana University Press, Bloomington, IN.

Shiloh, Y., 1984, Excavations at the city of David I (1978-1982) interim report of the first five seasons. Qedem 19, The Institute of Archaeology: Hebrew University, Jerusalem.

Smith, B.K. \& Page, F.S., 1995, 'Amos, Obadiah, Jonah', in The New American Commentary. An exegetical and theological exposition of holy scriptures (NIV Text), pp. 22-170, Broadman and Holman, Nashville, TN

Smith, G.V., 1989, Amos. A commentary, Zondervan, Grand Rapids, MI.

Smith, G.V., 2001, Hosea, Amos, Micah: NIV application commentary, Zondervan, Grand Rapids, MI.

Soggin, J.A., 1987, The prophet Amos. A translation and commentary, transl. J. Bowden, SCM, London.

Stulman, L., 1995, 'Insiders and outsiders in the book of Jeremiah: Shifts in symbolic arrangement', Journal for the Study of the Old Testament 66, 65-85. http://dx.doi. org/10.1177/030908929502006604

Timmer, D., 2014, 'The use and abuse of power in Amos: Identity and ideology', Journal for the Study of the Old Testament 39(1), 101-118. http://dx.doi org/10.1177/0309089214551516

Viberg, A., 1996, 'Amos 7:14: A case of subtle irony', Tyndale Bulletin 47(1), 91-114.

Wolff, H.W., 1977, Joel and Amos (Hermeneia), Fortress, Philadelphia, PA.

Wood, J.R., 1998, 'Tragic and comic forms in Amos', Biblical Interpretation 6, 20-48. http://dx.doi.org/10.1163/156851598X00219 